\title{
Erratum to: Hydroclimatic and hydrochemical controls on Plecoptera diversity and distribution in northern freshwater ecosystems
}

\author{
Laura M. Kruitbos $\cdot$ Doerthe Tetzlaff $\cdot$ Chris Soulsby $\cdot$ Jim Buttle $\cdot$ \\ Sean K. Carey • Hjalmar Laudon • Jeffrey J. McDonnell • Kevin McGuire • \\ Jan Seibert $\cdot$ Richard Cunjak $\cdot$ Jamie Shanley
}

Published online: 23 November 2012

(C) Springer Science+Business Media Dordrecht 2012

\section{Erratum to: Hydrobiologia (2012) 693:39-53 DOI 10.1007/s10750-012-1085-1}

The co-author Hjalmar Laudon acknowledges that in the above-mentioned publication the Plecoptera data from the Krycklan catchment have been used from Dr. Zlatko Petrin without prior consent. Hjalmar Laudon apologizes for this.
The online version of the original article can be found under doi:10.1007/s10750-012-1085-1.

L. M. Kruitbos $(\bowtie) \cdot$ D. Tetzlaff · C. Soulsby ·

J. J. McDonnell · J. Shanley

Northern Rivers Institute, School of Geosciences,

University of Aberdeen, Aberdeen, UK

e-mail: 1.kruitbos@abdn.ac.uk

\section{J. Buttle}

Department of Geography, Trent University,

Peterborough, ON, Canada

\section{S. K. Carey}

School of Geography and Earth Sciences,

McMaster University, Hamilton, ON, Canada

\section{H. Laudon}

Forest Ecology and Management, SLU, Umeå, Sweden

\section{J. J. McDonnell}

Department of Forest Engineering, Resources and Management, Oregon State University,

Corvallis, OR, USA

\author{
K. McGuire \\ Department of Forest Resources and Environmental, \\ Conservation, Virginia Water Resources Research Center, \\ Virginia Tech, Blacksburg, VA, USA \\ J. Seibert \\ Department of Geography, University of Zurich, Zurich, \\ Switzerland \\ J. Seibert \\ Department of Physical Geography and Quaternary \\ Geology, Stockholm University, Stockholm, Sweden \\ R. Cunjak \\ Canadian Rivers Institute, Department of Biology and the \\ Faculty of Forestry and Environmental Management, \\ University of New Brunswick, Fredericton, NB, Canada \\ J. Shanley \\ US Geological Survey, Reston, VT, USA
}

